University of Nebraska - Lincoln

DigitalCommons@University of Nebraska - Lincoln

\title{
Evaluating observed and projected future climate changes for the Arctic using the Köppen-Trewartha climate classification
}

\author{
Song Feng \\ University of Nebraska - Lincoln, sfeng2@unl.edu \\ Chang-Hoi Ho \\ Seoul National University, Seoul, Korea \\ Qi Hu \\ University of Nebraska, Lincoln, qhu2@unl.edu \\ Robert Oglesby \\ University of Nebraska - Lincoln, roglesby2@unl.edu \\ Su-Jong Jeong \\ Seoul National University, Seoul, Korea \\ See next page for additional authors
}

Follow this and additional works at: https://digitalcommons.unl.edu/natrespapers

Part of the Natural Resources and Conservation Commons

Feng, Song; Ho, Chang-Hoi; Hu, Qi; Oglesby, Robert; Jeong, Su-Jong; and Kim, Baek-Min, "Evaluating observed and projected future climate changes for the Arctic using the Köppen-Trewartha climate classification" (2011). Papers in Natural Resources. 291.

https://digitalcommons.unl.edu/natrespapers/291

This Article is brought to you for free and open access by the Natural Resources, School of at DigitalCommons@University of Nebraska - Lincoln. It has been accepted for inclusion in Papers in Natural Resources by an authorized administrator of DigitalCommons@University of Nebraska - Lincoln. 


\section{Authors}

Song Feng, Chang-Hoi Ho, Qi Hu, Robert Oglesby, Su-Jong Jeong, and Baek-Min Kim 
Published in Climate Dynamics (2011); doi: 10.1007/ s00382-011-1020-6

Copyright $\odot 2011$ Springer-Verlag. Used by permission.

Submitted October 25, 2010; accepted January 31, 2011; published online February 11, 2011.

\title{
Evaluating observed and projected future climate changes for the Arctic using the Köppen-Trewartha climate classification
}

\author{
Song Feng, ${ }^{1}$ Chang-Hoi Ho, ${ }^{2}$ Qi Hu, ${ }^{1,3}$ Robert J. Oglesby, ${ }^{1,3}$ Su-Jong Jeong, ${ }^{2}$ and Baek-Min Kim ${ }^{4}$
}

1. School of Natural Resources, University of Nebraska-Lincoln, 702 Hardin Hall, Lincoln, NE 68583-0987, USA

2. School of Earth and Environmental Sciences, Seoul National University, Seoul, Korea

3. Department of Earth and Atmospheric Sciences, University of Nebraska-Lincoln, Lincoln, NE, USA

4. Korean Polar Research Institute, Incheon, Korea

Corresponding author - Song Feng, email: sfeng2@unl.edu

\begin{abstract}
The ecosystems in the Arctic region are known to be very sensitive to climate changes. The accelerated warming for the past several decades has profoundly influenced the lives of the native populations and ecosystems in the Arctic. Given that the Köppen-Trewartha (K-T) climate classification is based on reliable variations of land-surface types (especially vegetation), this study used the K-T scheme to evaluate climate changes and their impact on vegetation for the Arctic (north of $50^{\circ} \mathrm{N}$ ) by analyzing observations as well as model simulations for the period 1900-2099. The models include 16 fully coupled global climate models from the Intergovernmental Panel on Climate Change Fourth Assessment. By the end of this century, the annualmean surface temperature averaged over Arctic land regions is projected to increase by $3.1,4.6$ and $5.3^{\circ} \mathrm{C}$ under the Special Report on Emissions Scenario (SRES) B1, A1b, and A2 emission scenarios, respectively. Increasing temperature favors a northward expansion of temperate climate (i.e., $D c$ and $D o$ in the K-T classification) and boreal oceanic climate (i.e., Eo) types into areas previously covered by boreal continental climate (i.e., $E c$ ) and tundra; and tundra into areas occupied by permanent ice. The tundra region is projected to shrink by $-1.86 \times 10^{6} \mathrm{~km}^{2}(-33.0 \%)$ in B1, $-2.4 \times 10^{6} \mathrm{~km}^{2}(-42.6 \%)$ in A1b, and $-2.5 \times 10^{6} \mathrm{~km}^{2}$ $(-44.2 \%)$ in $\mathrm{A} 2$ scenarios by the end of this century. The $E c$ climate type retreats at least $5^{\circ}$ poleward of its present location, resulting in $-18.9,-30.2$, and $-37.1 \%$ declines in ar-
\end{abstract}

eal coverage under the $\mathrm{B} 1, \mathrm{~A} 1 \mathrm{~b}$ and $\mathrm{A} 2$ scenarios, respectively. The temperate climate types $(D c$ and $D o$ ) advance and take over the area previously covered by Ec. The area covered by $D c$ climate expands by $4.61 \times 10^{6} \mathrm{~km}^{2}(84.6 \%)$ in B1, $6.88 \times 10^{6} \mathrm{~km}^{2}(126.4 \%)$ in A1b, and $8.16 \times 10^{6} \mathrm{~km}^{2}$ $(149.6 \%)$ in A2 scenarios. The projected redistributions of K-T climate types also differ regionally. In northern Europe and Alaska, the warming may cause more rapid expansion of temperate climate types. Overall, the climate types in 25, 39.1 , and $45 \%$ of the entire Arctic region are projected to change by the end of this century under the B1, A1b, and A2 scenarios, respectively. Because the K-T climate classification was constructed on the basis of vegetation types, and each K-T climate type is closely associated with certain prevalent vegetation species, the projected large shift in climate types suggests extensive broad-scale redistribution of prevalent ecoregions in the Arctic.

Keywords: Arctic, Köppen-Trewartha climate classification, Fully coupled global climate models, Climate projection, Vegetation

\section{Introduction}

The Arctic region is extremely vulnerable to climate change and its impacts. Observations show that surface air temperatures in the Arctic have warmed at about 
twice the global rate over the past few decades (ACIA 2004). This Arctic warming also is expressed through widespread melting of glaciers and sea ice and rising permafrost temperatures (e.g., Serreze et al. 2007; Zhang et al. 2005; Hinzman et al. 2005). Consistent with Arctic warming, the amount of rainfall in high latitudes has increased considerably over the past 50 years (Min et al. 2008), supporting earlier reported increases in Arctic river discharge (ACIA 2005; Peterson et al. 2002; Hinzman et al. 2005). Additionally, the Arctic warming leads to decreasing sea ice and snow cover as well as longer snow-free seasons (Chapin et al. 2005; Stone et al. 2002). The shrinking sea ice and snow cover and the lengthening of the snow-free season in turn reduce surface albedo and contribute substantially via a positive feedback to high-latitude warming trends (Chapin et al. 2005; McGuire et al. 2006; Jeong et al. 2010a).

A mounting body of evidence indicates that this recent, amplified warming in the Arctic is fueled by human-induced 'global warming' (e.g., Intergovernmental Panel on Climate Change (IPCC) 2007; Gillett et al. 2008). Gillett et al. (2008) examined the mechanisms underlying the observed polar climate changes using simulations made by multiple climate models included in the IPCC Fourth Assessment (AR4). Their work demonstrated convincingly that humans have indeed contributed to recent warming in the Arctic region. Additionally, increasing atmospheric concentrations of greenhouse gases are projected to further contribute to Arctic warming of about $4-7^{\circ} \mathrm{C}$ over next 100 years (ACIA 2004). These results emphasize the urgent need to understand observed and projected future climate changes and their impact on ecosystems in the Arctic.

Warming in the Arctic can, and apparently has already caused large shifts in vegetation. Plants in Greenland are flowering at an earlier date; indeed the onset of the growing season occurs earlier (Post et al. 2009; Matthes et al. 2009). The areal extent of tall shrubs in Alaska's North Slope tundra region has increased 1.2\% per decade since 1950 (Sturm et al. 2001), also supported by indigenous observations in the same region (Thorpe et al. 2002). Throughout Alaska, a majority of the studied sites show a treeline advance (Lloyd 2005). White spruce (Picea glauca) has expanded into what was tundra and increased in density in western Alaska (Lloyd et al. 2003). During the past 50 years, $2.3 \%$ of the treeless area has been converted from tundra to forest in Alaska (Chapin et al. 2005). This widespread expansion of shrubs, and advancing treeline in Alaska and other Arctic regions is also supported by rapid greening and earlier start of the growing season, as revealed by satellite-retrieved vegetation indices (Zhou et al. 2001; Tucker et al. 2001; Hinzman et al. 2005; Jia et al. 2009; Bhatt et al. 2010).
One simple, but frequently used method to assess the impact of climate change on ecosystems is the Köppen climate classification (Köppen 1936), and its subsequent modification to the Köppen-Trewartha (K-T) classification (Trewartha and Horn 1980). Though environmental and historical factors can exert important influences on natural vegetation at local scales, climate is nonetheless the fundamental factor regulating the broad-scale distribution of natural vegetation physiognomy and species composition. This is the main reason that Köppen used the natural vegetation of a region as an expression of its climate (Köppen 1936). The Köppen and K-T classifications combine temperature and precipitation regimes and their seasonality into a single metric and thereby classify global climate into several major types. Based on seasonal variations of temperature and precipitation, several sub-climate types in each major climate type can further be classified. The Köppen classification system has been widely used to describe the potential distribution of natural vegetation based on climatic thresholds thought to drive critical physiological processes (Bailey 2009). Indeed, each climate type (major or subclimate) is associated with a certain vegetation assemblage, or ecoregion, under present climate conditions (Bailey 2009; Baker et al. 2010; see also Table 1). Therefore, by definition the climate types are closely linked to the qualitative features of regional vegetation. Also of importance, a key advantage of this type of classification scheme is that it is easy to use with a variety of data sets and model outputs.

A number of previous studies used the Köppen and related climate classifications to investigate the potential impact of past, present, and projected future climate changes (Fraedrich et al. 2001; Wang and Overland 2004; de Castro et al. 2007; Baker et al. 2010; Gerstengarbe and Werner 2009). Fraedrich et al. (2001) analyzed changes in climate types over global land regions during 1901-1995. They reported that the area covered by tundra (which primarily appears in the Arctic) significantly declined during the 20th century. Wang and Overland (2004) used an updated dataset and reported a rapid decrease in circum-Arctic tundra coverage since 1990. De Castro et al. (2007) analyzed simulations made by multiple regional climate models and reported that the tundra in Northern Fennoscandia may shift to temperate climate types by 2071-2100 under the Special Report on Emissions Scenario (SRES) A2 scenario. Baker et al. (2010) used a multivariate spatial-temporal clustering algorithm in conjunction with the K-T classification scheme to quantify the impact of temperature and precipitation on ecoregions in China. They reported that the climate changes projected by the HadCM3 model under the SRES A1F1 scenario were sufficient to cause shifts in spatial distributions of the majority of ecoregions in China for 2041-2070. However, these previous 
Table 1. The classification criteria, description and the corresponding prevalent vegetation of the Köppen-Trewartha climate classification

\begin{tabular}{|c|c|c|c|}
\hline Climate type & Description & Prevalent vegetation (Bailey 2009) & Classification criteria \\
\hline Eo & Boreal oceanic & Needle leaf forest & $\begin{array}{l}\text { Up to } 3 \text { months above } 10^{\circ} \mathrm{C} \text { and the temperature } \\
\text { of the coldest month above }-10^{\circ} \mathrm{C}\end{array}$ \\
\hline $\mathrm{Ft}$ & Tundra & Tundra & The warmest month below $10 \mathrm{C}$ but above $0^{\circ} \mathrm{C}$ \\
\hline $\mathrm{Fi}$ & Ice cap & Permanent ice cover & All months $<0^{\circ} \mathrm{C}$ \\
\hline
\end{tabular}

studies using Köppen and related classification have focused on climate change during the instrumental period, or future changes in specific regions (e.g., China and Europe), and/or for a single SRES scenario. No previous studies have applied the Köppen and related classification schemes to a comprehensive examination of climate changes throughout the Arctic using both observations and a suite of projected future climate changes. The present study addresses this deficiency and applies the K-T classification to investigate climate changes in the Arctic region, which is defined as north of $50^{\circ} \mathrm{N}$. We employ newly updated observations and newly developed, statistically-downscaled high-resolution climate changes projected by 16 fully coupled climate models for various SRES scenarios.

Details of the observed and modeled climate data and the methods used to analyze those data are described in Sect. 2. The ability of the climate models to reproduce present observed climate types in the Arctic, as well as projected future changes in climate types, are presented in Sect. 3, followed by discussion in Sect. 4 and conclusion in Sect. 5.

\section{Data and methods}

The modified K-T climate classification (Trewartha and Horn 1980) is used to examine changes in climate types for the Arctic (north of $50^{\circ} \mathrm{N}$ ). This modified classification scheme identifies six major climate types using letters $A$ to $F$ : $A$-tropical, $B$-dry climate, $C$-subtropical, $D$-temperate, E-boreal, and F-polar. Based on seasonal variations of temperature and precipitation, several subclimate types are also classified for each major climate type. For example, the climate type $B$ is based on moisture availability and the other climate types are based on large-scale thermal zones. Due to the relatively cold temperatures, only climate types $D, E$, and $F$ are identified in the Arctic region. (While a small part of the tar- get region is projected as type $C$ by the end of the 21st century, this climate type is neglected because it only appears in less than $0.1 \%$ of the total Arctic area.) Additionally, because of the meager precipitation in the Arctic, the climate classifications there are merely based on monthly mean air temperature (Table 1 ). This is attributed to the fact that the growth of vegetation in cold regions such as the Arctic is mainly regulated by temperature (Tucker et al. 2001; Zhou et al. 2001).

The criteria used to classify the climate types, and the prevalent vegetation associated with each type, are listed in Table 1. Note that each sub-climate type is dominated by distinct vegetation zones (Köppen 1936; Trewartha and Horn 1980; Bailey 2009). For example, Ft is dominated by treeless tundra, while Do is dominated by dense coniferous forests with large trees. The shift of climate types in a specific region due to climate changes indicates that the dominant vegetation type in that region is replaced by other vegetation.

To evaluate climate changes and their impact on vegetation in the Arctic, both observed and projected future surface air temperatures are examined. Global climate model output, from the World Climate Research Programme's (WCRP's) Coupled Model Intercomparison Project phase 3 (CMIP3) multi-model dataset (Meehl et al. 2007), was obtained from http:// www.engr.scu.edu/ emaurer/global_data/. These data were downscaled as described by Maurer et al. (2009) using the bias-correction/spatial downscaling method (Wood et al. 2004) to a $0.5^{\circ}$ grid, based on the 1950-1999 gridded observations of Adam and Lettenmaier (2003). The statistically-downscaled present-day control simulations and future climate change projections from 16 fully coupled atmosphere-ocean models cover the global land surface for the period from 1950 to 2099. The future climate change projections include low, median and high greenhouse gas emission rates, termed SRES B1, A1b, and A2, respectively (Nakićenović and Swart 2000). 
In addition to the modeled temperature data, two observed temperature datasets were analyzed. The first is the half-degree resolution temperature dataset developed by Adam and Lettenmaier (2003), henceforth AL. This temperature dataset covers the period 1950-1999 and was also used to calibrate the modeled temperatures (Maurer et al. 2009). The second is the Terrestrial Air Temperature: 1900-2008 Gridded Monthly Time Series (version 2.01) developed by the Center for Climate Research at University of Delaware, henceforth UD. This dataset, obtained from http://www.climate.geog. udel.edu/ climate/, merges several updated gauge observed temperatures that are interpolated to grid points covering the global land surface at a $0.5^{\circ} \times 0.5^{\circ}$ horizontal resolution. The spatial interpolations were based on Willmott et al.'s (1985) spherical implementation of Shepard's spatial-interpolation algorithms, which also incorporated digital elevation model-assisted and climatological-aided interpolation methods. Compared to other existing observation-based land surface air temperature data, this dataset can reasonably capture the observed climatology, and departures from the mean state (anomaly fields) both regionally and globally.

Because the two observed temperature datasets used a slightly different number of observations as well as different spatial interpolation methods, the long-term mean of the UD temperature is slightly cooler than the corresponding AL temperature in most of the Arctic region during the overlapped period, 1950-1999 (figure not shown). The K-T climate classification using the UD temperatures therefore also shows slightly more area covered by colder climate types (e.g., polar climate) compared to AL temperatures (Table 2). To reduce the difference between the two observed datasets and for better comparison with the projected climate changes, the UD temperature is adjusted so that it has the same monthly climatological mean as the AL temperature. Specifically, the monthly anomalies of the UD temperatures during 1900-2008 were first calculated based on the 1950-1999 climatological mean of the UD temperature, then the 1950-1999 monthly climatological mean of the AL temperature is added to those monthly anomalies. The adjusted UD temperatures generate nearly identical climate classifications as the AL temperatures, and the IPCC AR4 models, during the overlapped period (1950-1999, see Table 2). The agreement between the observed and modeled data warranting further examination the long-term climate change from 1900 to the end of the 21st century.

The K-T climate classification is applied to both observed and projected future temperature changes in the Arctic region. Because different models contain different atmospheric and oceanic adjustment processes, the projected temperature changes by the models differ somewhat. It has been suggested that the simple average (or ensemble) of the model outputs made by all the available climate models is often the best determinant for simulating the mean global climate (e.g., Gleckler et al. 2008; Reichler and Kim 2008). This ensemble strategy can also be valid for regional climate change detection (Pierce et al. 2009). Therefore, the ensemble means of the 16 models for each SRES scenario are analyzed in this study. To help evaluate the uncertainties of the model projections, the standard deviations of the model projections for each SRES scenario are also computed. Additionally, to evaluate the temporal variations of the climate types, a 15-year equal weight smoothing is applied to the observed and projected temperature data to remove year to year fluctuations. Fraedrich et al. (2001) suggested that a 15-year smoothing is the optimal averaging interval (window) for the Köppen and related classifications.

\section{Results}

\subsection{Observed and projected temperature change}

To understand temporal variations in the Arctic region as the whole, the areal-weighted average temperature anomalies were calculated over the entire domain. Figure 1 shows this domain-averaged temperature for 1900-2099. The observed temperatures show strong interannual variations, which are superimposed on longer time-scale multidecadal changes. The temperature increases from 1900 to the middle 1940s, slowly decreases until the middle 1960s, followed by steady increase and amplified warming since the late 1970s. The ensemble of modeled temperature and the uncertainties of the model simulations are also depicted in the figure. The large standard deviations of the 16 model simulations suggest that some models may do a poor job in simulating the observed temperature. When the simulations of the 16 models are averaged, however, the biases in individual models are smoothed out, yielding variations consistent with the observations, e.g., cooling trend before the 1960s and steady warming trend since the late 1970s. These results support the previous finding that multiple model ensembles usually do a better job in simulating observed climate changes (Gleckler et al. 2008; Reichler and Kim 2008; Pierce et al. 2009).

The recent warming is projected to continue under all three SRES scenarios (Figure 1). By the end of this century, the winter temperature averaged over the entire Arctic land region is projected to increase by $4.2^{\circ} \mathrm{C}$ in $\mathrm{B} 1,6.1^{\circ} \mathrm{C}$ in $\mathrm{A} 1 \mathrm{~b}$, and $7.1^{\circ} \mathrm{C}$ in $\mathrm{A} 2$ scenarios. The warming in summer is much weaker than in winter. The summer temperature averaged over the entire Arctic is projected to increase by $2.2^{\circ} \mathrm{C}$ in $\mathrm{B} 1,3.3^{\circ} \mathrm{C}$ in $\mathrm{A} 1 \mathrm{~b}$, and $3.9^{\circ} \mathrm{C}$ in $\mathrm{A} 2$ scenarios. When all seasons are averaged, the annual temperature is projected to increase by $3.1^{\circ} \mathrm{C}$ in B1, $4.6^{\circ} \mathrm{C}$ in $\mathrm{A} 1 \mathrm{~b}$, and $5.3^{\circ} \mathrm{C}$ in $\mathrm{A} 2$ scenarios. 


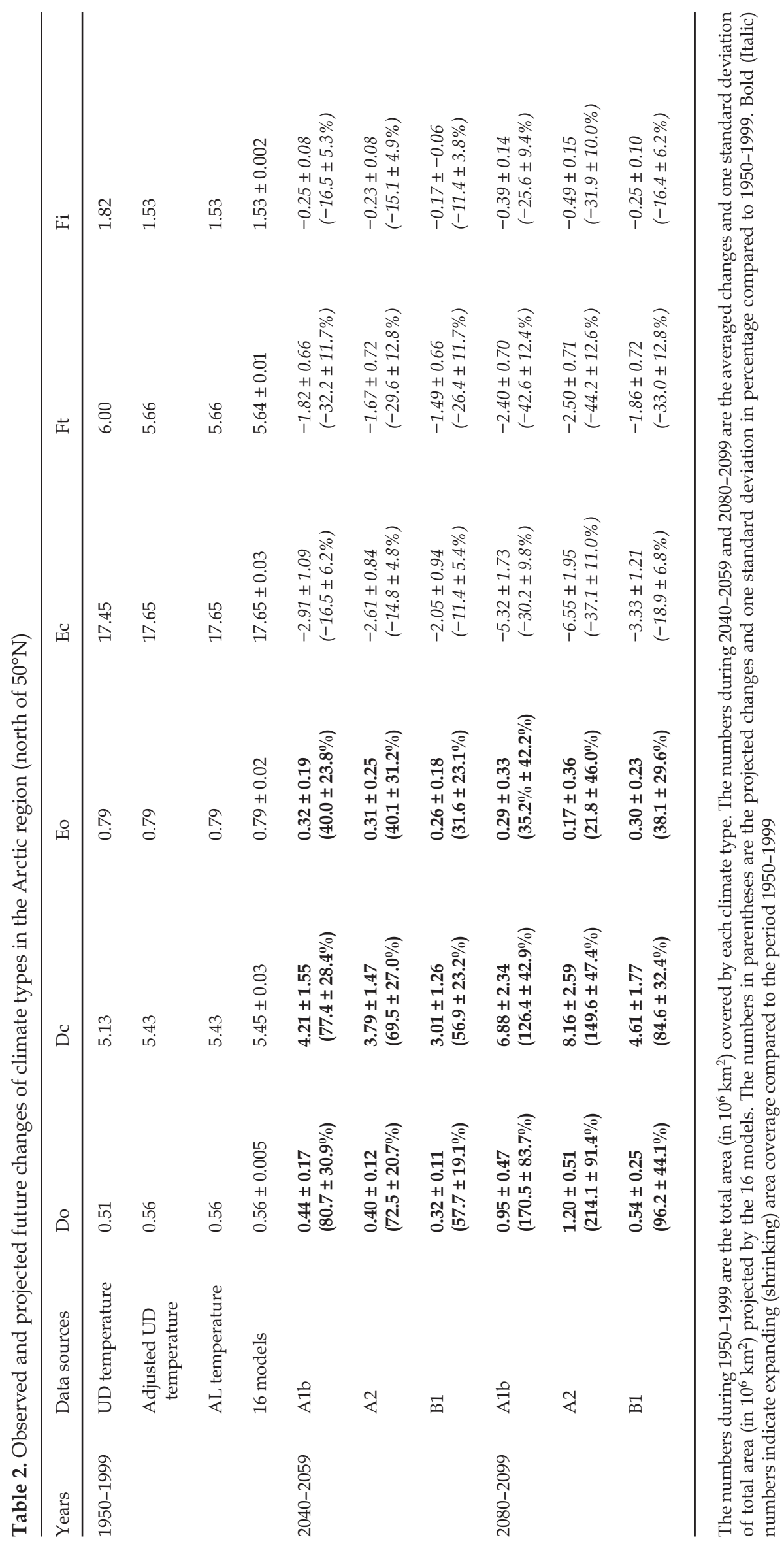



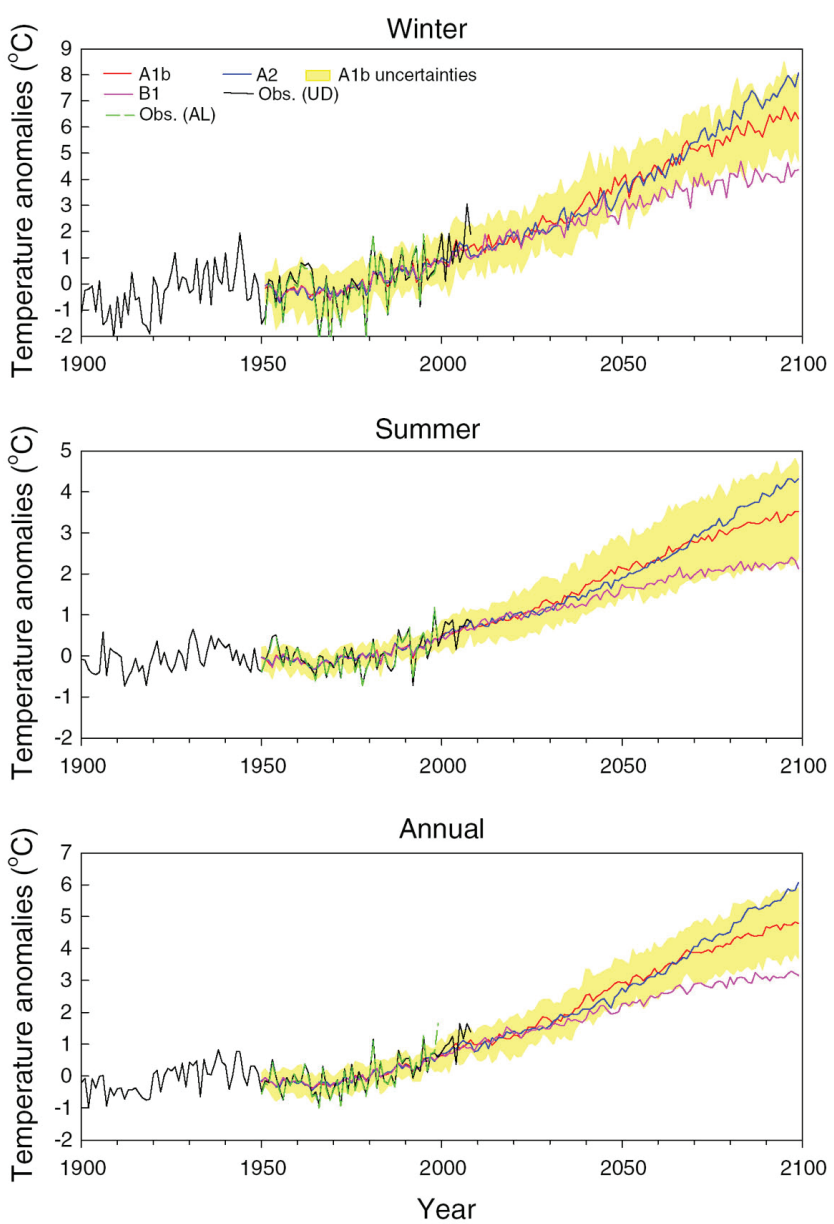

Figure 1. Areal weighted temperature changes in the Arctic during 1900-2099. The temperature anomalies are based on the 1950-1999 climatological mean. The black solid line is the temperature anomalies based on the adjusted temperature dataset from University of Delaware, and green dashed line is the temperature anomalies based on the temperature dataset developed by Adam and Lettenmaier (2003). The pink, red and blue lines are the ensembles of the projected temperature changes under SRES B1, A1b, and A2 scenarios, respectively. The yellow shading shows the standard deviations of the temperature anomalies from the 16 model projections under A1b scenarios

The warming signals, however, are not homogeneously distributed across the Arctic (Figure 2). In winter, warming of $2-10^{\circ} \mathrm{C}$ is projected by the end of this century under the A1B scenario. Strongest warming $\left(>7^{\circ} \mathrm{C}\right)$ appears along the Arctic coast regions. Moderate warming $\left(5-6^{\circ} \mathrm{C}\right)$ appears in most of southern Russia and southern Canada. The weakest warming $\left(2-3^{\circ} \mathrm{C}\right)$ occurs in southern Greenland, Iceland, and Western Europe. By contrast, the regional warming is much weaker in summer. The strongest summer warming $\left(3-4^{\circ} \mathrm{C}\right)$ occurs in the southern portions of the Arctic, i.e., southcentral Canada and southwestern Siberia. Moderate warming $\left(2-3^{\circ} \mathrm{C}\right)$ is projected for Alaska, far-eastern
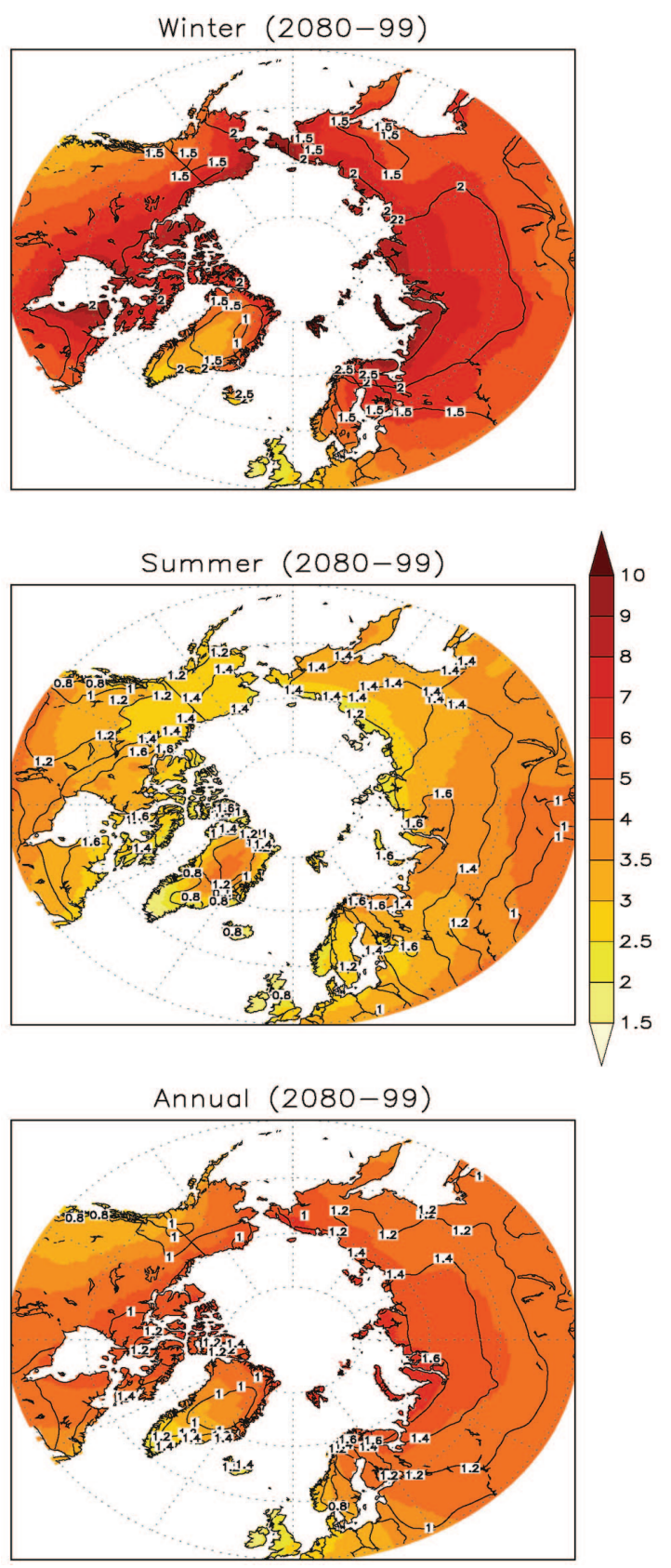

Figure 2. Spatial distributions of the projected temperature changes during 2080-2099 under SRES A1b scenario. The projected changes are the ensemble of the 16 fully coupled models. The contour lines show the standard deviation of the projected changes among the 16 models

Russia and the Arctic coastal regions. The weakest warming $\left(<2.0^{\circ} \mathrm{C}\right)$ is projected for southern Greenland, Iceland and Western Europe.

The spatial distribution of the annual temperature warming is similar to that during winter, except the magnitude of the warming is slightly smaller (about $2-8^{\circ} \mathrm{C}$ warming). Despite the overall strong warm- 
ing throughout the Arctic, the warming in southern Greenland, Iceland, and western Europe is relatively weak $\left(1.5-2.0^{\circ} \mathrm{C}\right)$. The projected weak warming in these regions is likely caused by accelerating melt of snow in Greenland and sea ice in the Arctic Ocean (Dima and Lohmann 2007) as energy is going into melting, rather than warming. Though the spatial distributions of the projected warming are noticeably different between winter and summer, the spatial distributions of the model uncertainties are fairly similar for all seasons. These uncertainties among the model projections are evaluated by calculating the standard deviation of the temperature changes projected by the 16 models. As shown in Figure 2, large uncertainties (that is, large standard deviation of the projected changes among the 16 models) of the projected warming occur in northern Greenland and Arctic coastal regions. The uncertainties in southern Canada and southern Russia are relatively small. These projected temperature warmings are comparable with previous studies for the Arctic regions (ACIA 2004). Our results, however, are based on an ensemble of 16 models included in IPCC AR4. The statistically-downscaled high spatial resolution data also provide more local detail of the projected changes in the Arctic region. Nonetheless, it is reassuring that our results are similar to those obtained previously as it increases confidence in their robustness.

\subsection{Spatial distribution of the K-T climate types}

To examine the impact of these large Arctic warmings on vegetation type, the K-T climate classification is calculated using both observed and projected temperature datasets. Figure 3a shows the spatial distribution of each climate type during 1950-1999 based on the adjusted UD temperature dataset. The spatial distribution of the climate types based on the AL temperature dataset and the ensemble of the 16 climate models during 1950-1999 is very similar to that based on the adjusted UD temperature (see Table 2, figures omitted). The temperate oceanic climate $(D o)$ is found in Western Europe, and some small regions near the west Canadian coast. The tundra climate $(F t)$ is mainly found in northern Canada and coastal regions around the Arctic Ocean. Scattered regions of tundra are also found in the mountains of southern Alaska, and in far-eastern Russia. The spatial distribution of tundra in the Arctic closely matches those regions enclosed by mean summer temperatures between -5 and $5^{\circ} \mathrm{C}$ (figure not shown). Matthes et al. (2009) analyzed the growing degree days, the accumulated temperature for daily mean temperature warmer than $5^{\circ} \mathrm{C}$, in the Arctic region. Their results showed that annual growing degree days in regions occupied by tundra climate are normally less than $600^{\circ} \mathrm{C}$, suggesting very little heating energy available for vegetation growth in those regions. Wang and Overland

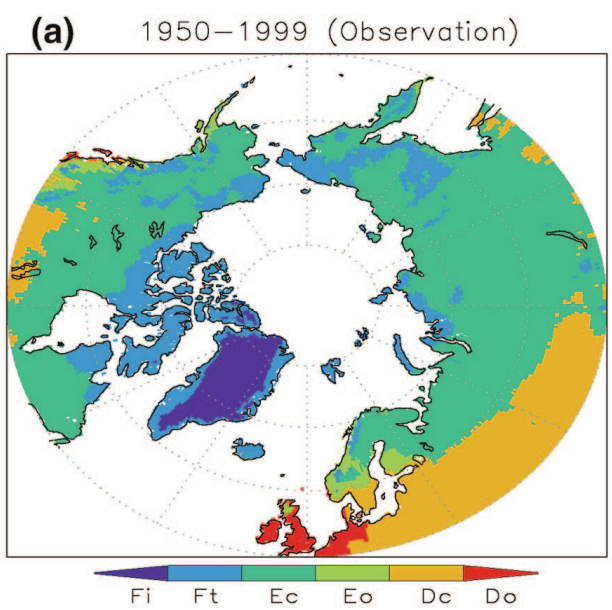

(b) $\quad 2040-2059($ A1 b)

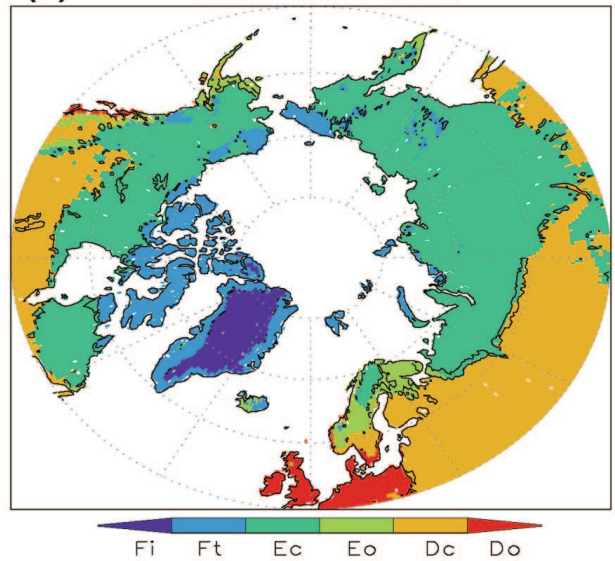

(c) $\quad 2080-2099(\mathrm{~A} 1 \mathrm{~b})$

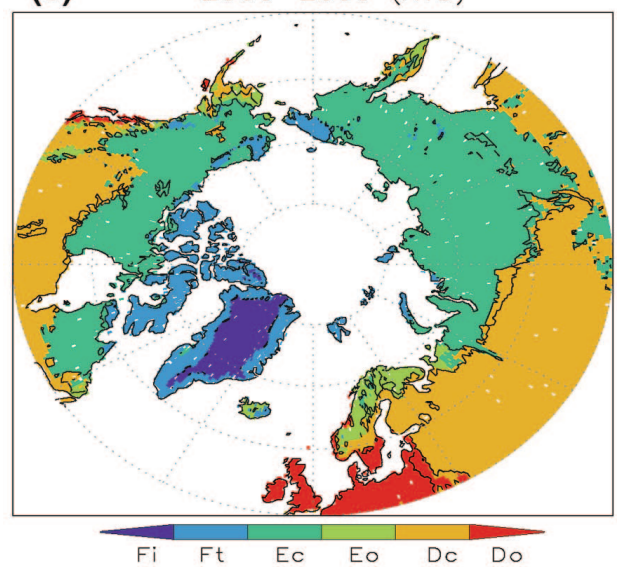

Figure 3. Spatial distribution of K-T climate sub-types. a) is deduced from the long-term average (1950-1999) temperature dataset of the adjust UD temperature, and $\mathbf{b}$ ) and c) are deduced from the ensemble of the projected temperature during 2040-2059 and 2080-2099 under A1b scenarios. The contour lines in $\mathbf{b})$ and $\mathbf{c}$ ) outline regions with 9 or fewer models assigned the same climate types as the ensemble

(2004) also showed that the vegetation cover in regions occupied by tundra climate is quite low, with NDVI values ranging from 0.1 to 0.4 in July and August. The correspondence of regions covered by tundra with mean 
summer temperatures between -5 and $5^{\circ} \mathrm{C}$, few growing degree days, and low vegetation growth all support previous studies (Köppen 1936; Bailey 2009) that suggest the K-T climate types can reasonably describe the dominant vegetation throughout the Arctic.

To evaluate the impact of projected climate change on vegetation assemblages, the spatial distributions of the climate types as simulated by the 16 climate models are analyzed. For simplicity, only the spatial distribution of the climate types projected by A1b (ensemble of the 16 models) in the middle (2040-2059) and end (2080-2099) of this century are displayed in Figure 3. Compared to present-day conditions (Figure 3a), noticeable shifts in climate types are projected for the middle and end of this century. For example, the areal extent of tundra in Alaska is substantially reduced during 20402059 , being replaced by forests of the boreal continental climate $(E c)$. The tundra will be further reduced, being mainly restricted to the north coast of Alaska by 20802099. In northern Canada, the warming pushes the distribution of tundra poleward to the coast of the Arctic Ocean and adjacent islands during 2040-2059. The tundra will be restricted to the islands in the Arctic Ocean during 2080-2099. On the other hand, the melting of snow and ice in Greenland following the warming will reduce the permanent ice cover $(F i)$, giving its territory up to tundra $(F t)$.

Following the northward contraction of tundra and permanent ice, the boreal oceanic (Eo), Do, and Dc types are projected to expand northward. In eastern Europe and western Siberia $\left(30^{\circ} \mathrm{E}-90^{\circ} \mathrm{E}\right)$, the boreal continental climate $(E c)$ is found south of $60^{\circ} \mathrm{N}$ during $1950-1999$ (Figure $3 \mathrm{a}$ ). With the projected warming, this climate type is projected to retreat to approximately $62^{\circ} \mathrm{N}$ during 2040-2059 and $65^{\circ} \mathrm{N}$ during 2080-2099 (Figure 3). On the other hand, the Do and Dc climate types advance into the areas originally covered by $E c$. In middle and eastern North Asia $\left(90^{\circ} \mathrm{E}-150^{\circ} \mathrm{E}\right)$, the Ec climate occurs from south of $50^{\circ} \mathrm{N}$ to the Arctic coast during 1950-1999. This climate type almost disappears, and is replaced by the $D c$ climate during 2080-2099 in regions south of $55^{\circ} \mathrm{N}$ in middle and eastern North Asia. In other words, with the projected warming under the mid-range ARES A1b scenario, the $E c$ climate zone in middle and eastern North Asia shifts from south of $50^{\circ} \mathrm{N}$ during 1950-1999 to north of $55^{\circ} \mathrm{N}$ by the end of the 21st century. A more than $5^{\circ}$ northward retreat of Ec climate is also projected for North America during 2080-2099 (Figure 3).

In Europe, the Do climate is projected to expand north and east into Western Europe (around $25^{\circ} \mathrm{E}$ ) by the end of this century. The tundra in Scandinavia during 1950-1999 will be substantially reduced during 2040-2059, almost totally disappearing by 2080-2099. Scandinavia will then be dominated by the Eo climate. Similar changes are also projected using simulations made by multiple regional climate models (de Castro et al. 2007).

While the ensemble of the 16 global models shows a systematic redistribution in climate types, there are some differences among the models. Because it is impractical to display the projected climate types for each model, Figure 3 shows the uncertainties of the 16 models in describing the projected changes in K-T climate types. The uncertainties are evaluated by comparing the K-T climate types projected by the model ensemble with individual models. In particular, for a given grid cell, if more than 10 models projected the same climate type as the ensemble mean, it suggests that majority of the models (two thirds) are in agreement for that grid cell. It also implies that model projections for that grid cell contain fewer uncertainties. For a majority of Arctic regions, at least 10 or more models projected the same climate types as the ensemble (Figure 3). Regions with less agreement among the models (shown in contour lines) are mainly located in western and middle Siberia. These disagreements become larger during 20802099 compared to during 2040-2059, suggesting that the biases in individual model increase with time. These disagreements are consistent with the models containing different atmospheric, oceanic and land surface processes. These disagreements, however, are relatively small and mostly located along the boundary of climate types. They also suggest that, despite the biases in individual models, the ensemble of the 16 models may well describe the projected climate changes.

The total areas occupied by each climate type during 2040-2059 and 2080-2099 for all the three SRES scenarios are listed in Table 2. As seen in the table, noticeable changes are projected for these two periods. Overall, the areas occupied by polar climate (i.e., $F i$ and $F t$ ) and boreal continental climate (i.e., $E c$ ) are projected to decline, while the temperate (i.e., Do and $D c$ ) and boreal oceanic (i.e., Eo) climate types are expected to expand in the Arctic region. Of these 6 climate types, the $E c$ and Ft show the most decline with the warming. The tundra cover is expected to shrink by $-1.82 \times 10^{6} \mathrm{~km}^{2}$ and $-1.67 \times 10^{6} \mathrm{~km}^{2}$ (or -32.2 and $-29.6 \%$, respectively) under SRES A1b and A2 scenarios by 2040-2059. Additional $0.9 \times 10^{6} \mathrm{~km}^{2}$ to $1.0 \times 10^{6} \mathrm{~km}^{2}$ reductions are projected for the two scenarios, respectively, by the end of this century. By contrast, the reduction in tundra is less under the stronger stabilization SRES scenario B1. The simulated area occupied by $E c$ will be reduced by $-2.05 \times 10^{6} \mathrm{~km}^{2}(-11.4 \%),-2.91 \times 10^{6} \mathrm{~km}^{2}(-16.5 \%)$, and $-2.61 \times 10^{6} \mathrm{~km}^{2}(-14.8 \%)$ during $2040-2059$ under SRES $\mathrm{B} 1, \mathrm{~A} 1 \mathrm{~b}$, and A2 scenarios, respectively. The reduction increases to $-3.33 \times 10^{6} \mathrm{~km}^{2}(-18.9 \%),-5.32 \times 10^{6} \mathrm{~km}^{2}$ $(-30.2 \%)$, and $-6.55 \times 10^{6} \mathrm{~km}^{2}(-37.1 \%)$ for the three scenarios, respectively, during 2080-2099. On the other hand, the area occupied by Dc, Do, and Eo types are pro- 
jected to expand with all three SRES scenarios. The most noticeable expansion is projected for $D c$, with a greater than $3.0 \times 10^{6} \mathrm{~km}^{2}$ increase in Dc projected during 20402059. Coverage then increases by $4.61 \times 10^{6} \mathrm{~km}^{2}$ (or $84.6 \%$ ), $6.88 \times 10^{6} \mathrm{~km}^{2}$ (or 126.4\%), and $8.16 \times 10^{6} \mathrm{~km}^{2}$ (or $149.6 \%$ ) under B1, A1b, and A2 scenarios, respectively, during 2080-2099. As shown in Figure 3, the expansion of $D c$ is mainly because the area occupied by this climate type in 2080-2099 increases by at least $5^{\circ}$ north of its present-day conditions (1950-1999).

\subsection{Temporal variations of the K-T climate types}

The evolution of the Arctic regions occupied by each climate type has also been analyzed. Figure 4 shows the temporal variations of the total area occupied by each climate type during the entire analysis period 19002099. The observations show a weak trend toward reducing tundra cover from the beginning of the 20th century to the 1940s. This decrease in tundra coverage leveled off from middle 1940 to 1970s, followed by an even more abrupt decrease during the recent 40 years. Similar trends have been observed by Wang and Overland (2004), using a different observed temperature dataset for the period 1901-2000. The models projected a steady decline in tundra coverage. The projected decline rates in tundra coverage are $-0.16 \times 10^{6} \mathrm{~km}^{2}(-2.7 \%)$, $-0.22 \times 10^{6} \mathrm{~km}^{2}(-3.8 \%)$, and $-0.23 \times 10^{6} \mathrm{~km}^{2}(-4.0 \%)$ per decade for the B1, A1b and A2 scenarios, respectively.

The changes of $D c$ coverage during the instrumental period also show interdecadal variations. The area covered by Dc steadily expands from the early 1900s to the late 1940s, but then slowly shrinks until the late 1970s, followed by a steady expansion over the last few decades (Figure 4). This multidecadal change in Dc coverage is closely related to the observed temperature changes in the Arctic during the last 100 years (Figure 1). Recent expansions in Dc coverage are projected to continue by all the SRES scenarios. The area occupied by $D c$ is projected to increase by $0.43 \times 10^{6} \mathrm{~km}^{2}(7.8 \%)$, $0.72 \times 10^{6} \mathrm{~km}^{2}(13.0 \%)$, and $0.81 \times 10^{6} \mathrm{~km}^{2}(14.7 \%)$ per decade for the B1, A1b, and A2 scenarios, respectively.

In order to evaluate the change of climate types on regional scales, the temporal variations of the areal coverage of each climate type for Northern Europe $\left(50^{\circ} \mathrm{N}-\right.$ $75^{\circ} \mathrm{N}$ and $\left.12^{\circ} \mathrm{W}-40^{\circ} \mathrm{E}\right)$ and Alaska $\left(50^{\circ} \mathrm{N}-75^{\circ} \mathrm{N}\right.$ and $130^{\circ} \mathrm{W}-168^{\circ} \mathrm{W}$ ) were also analyzed. In northern Europe, the projected changes of each climate type are more complicated as compared to the entire Arctic region, suggesting differing regional responses to large scale warming (Figure 5). Persistent expansions in Do coverage are projected by all SRES scenarios, while the coverage of $D c$ and Eo are projected to slowly expand until the 2040s, and then slowly decline. The warming allows the $D c$ and Eo types to move north and eastward,

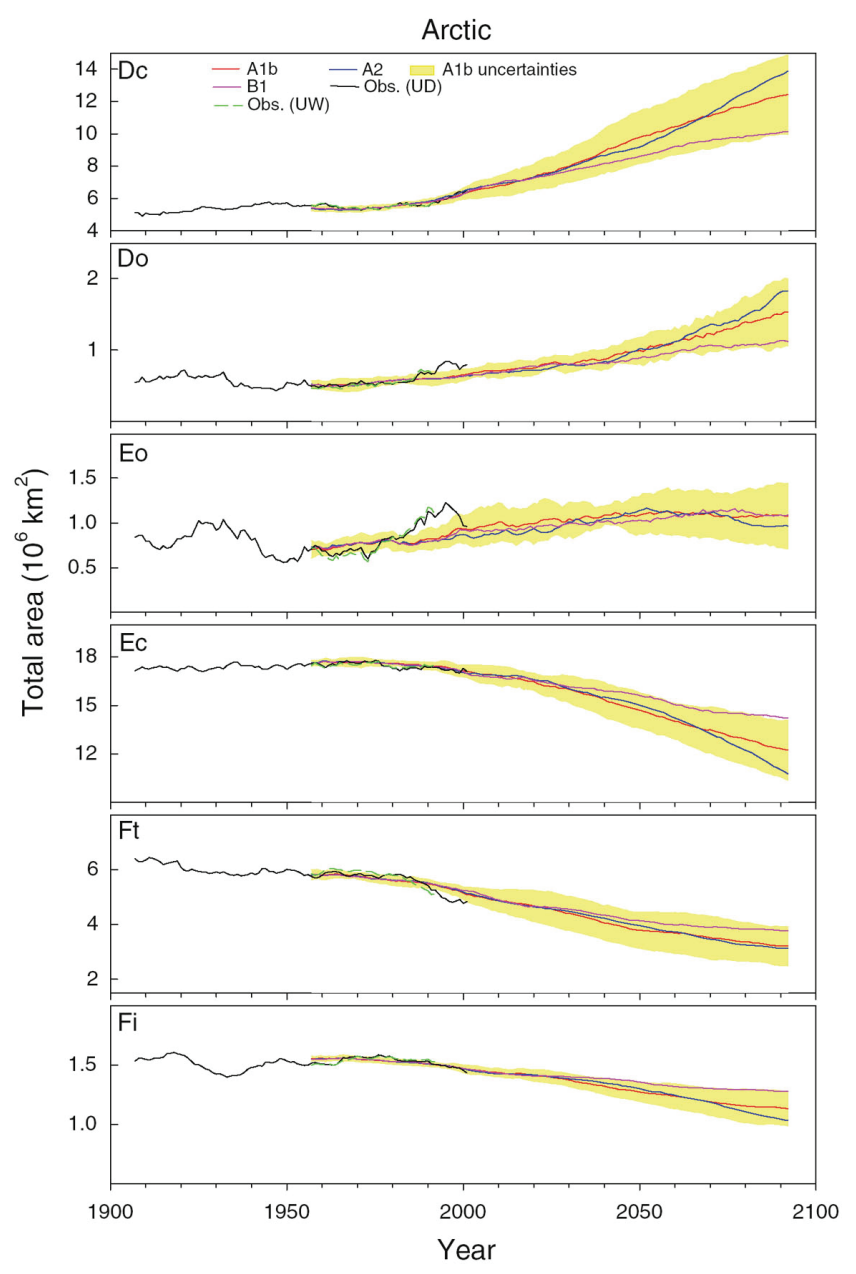

Figure 4. Time series of the total areas occupied by each climate types in the Arctic region. The black solid lines are the temporal variations based on the adjusted temperature dataset from University of Delaware, and green dashed lines are based on the temperature dataset from Adam and Lettenmaier (2003). The pink, red and blue lines are the ensemble of the projected total area changes under SRES B1, A1b, and A2 scenarios, respectively. The yellow shading shows the standard deviations of the total area coverage of the 16 model projections under A1b scenarios. A 15-year equal weight smoothing is applied to the observed and projected temperature data before the K-T climate classification is calculated.

into those areas formerly occupied by Ft and Ec. On the other hand, the Do climate type is also projected to move north and east, expanding into regions previously covered by Dc and Eo (Figure 3). The expansion of Do coverage markedly increases after 2040, consistent with the slow decline in $D c$ and Eo (Figure 5).

Alaska is dominated by both Ec and Ft climate types. The two occupy about $1.95 \times 10^{6} \mathrm{~km}^{2}$ (or $90 \%$ of the land region in Alaska) during the instrumental period (Figure 6). Tundra covers about $0.72 \times 10^{6} \mathrm{~km}^{2}$ (or $32 \%$ of Alaska) during the 1950 and 1960s, then gradually declines until the 1990s. The coverage of tundra then 

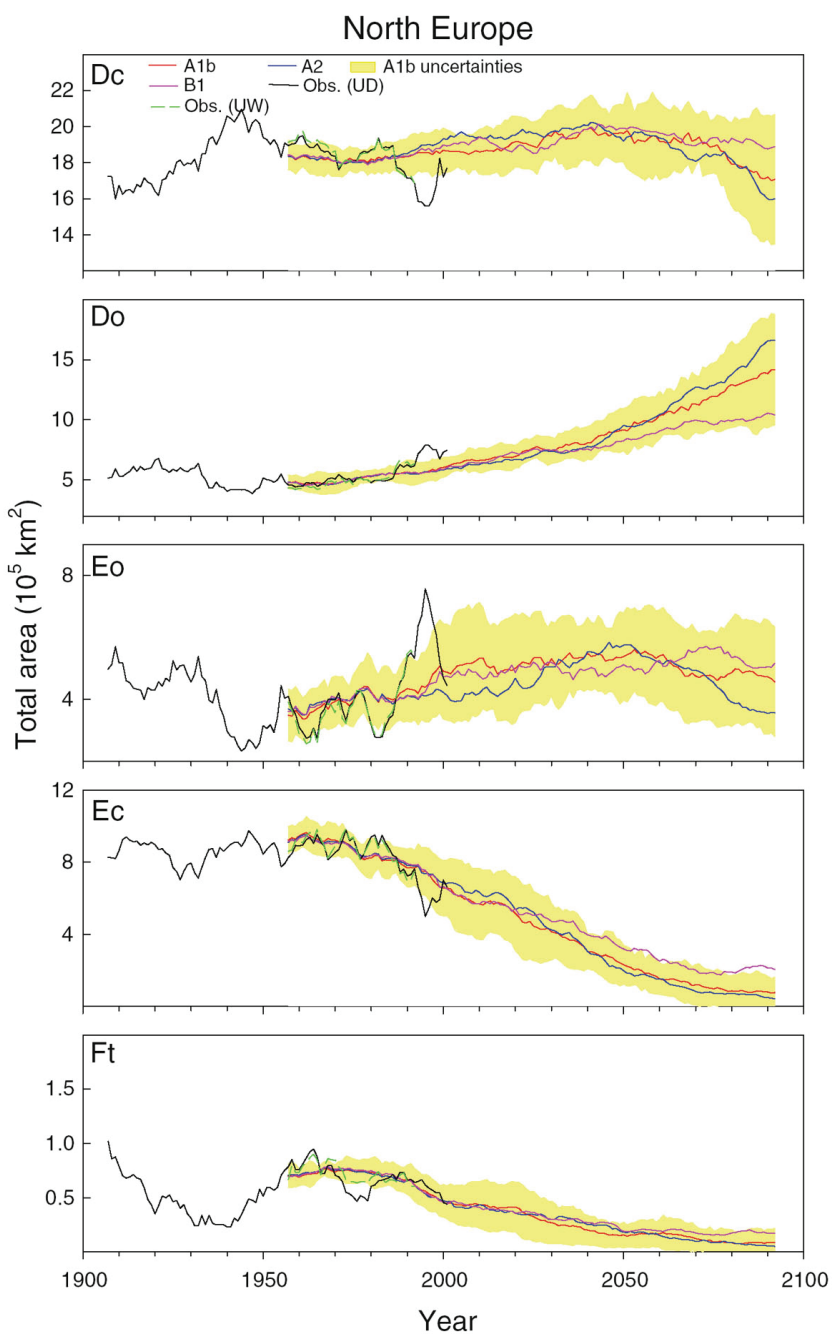

Figure 5. Same as Figure 4 but for Northern Europe $\left(50-75^{\circ} \mathrm{N}\right.$ and $12^{\circ} \mathrm{W}-40^{\circ} \mathrm{E}$ ). The ' $\mathrm{Fi}^{\prime}$ climate type is not shown because it does not exist in Europe.

slightly increased in recent years. Decreasing area occupied by tundra is projected for all three SRES scenarios, so that it just covers about $0.2-0.3 \times 10^{6} \mathrm{~km}^{2}$ (or 10$15 \%$ of Alaska, depending on the SRES scenarios) by the end of this century. This reduction in tundra is largely replaced by increasing coverage of $E c$. The coverage of $E c$ and $F t$ both varied on bi-decadal and longer timescales, but the fluctuations and the trend of their coverage are nearly out of phase during the instrumental period. This overall out-of-phase relationship between the coverage of the two climate types is projected to continue until the 2050s. Ec is projected to increase until the middle of this century, followed by an even sharper decline. Similar decline in areal coverage in the second half of this century is also projected for the Eo climate type. Those projected declines after the 2050s are consistent with the northward shift of Do and Dc (Figs. 3 and 6) during that same period into a region where they did not occur during the observational period. The cover-

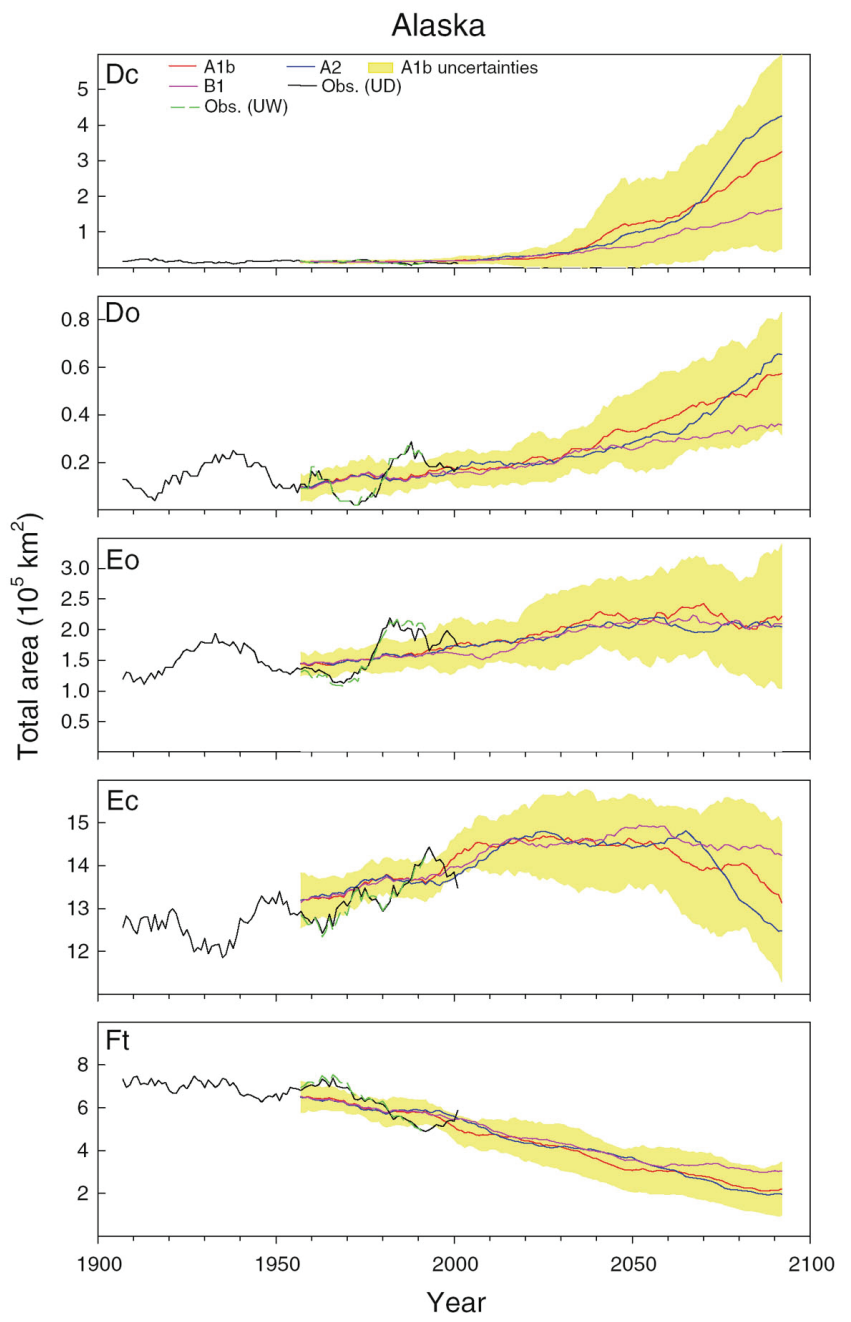

Figure 6. Same as Figure 4 but for Alaska $\left(50-75^{\circ} \mathrm{N}\right.$ and $130-$ $\left.168^{\circ} \mathrm{W}\right)$. The ' $\mathrm{Fi}^{\prime}$ climate type is not shown because it does not exist in Alaska.

age of $D c$ and Do combined is less than $0.015 \times 10^{6} \mathrm{~km}^{2}$ of the total area in Alaska before 2050, but then is predicted to increase sharply by 2100 . These results suggest that, though the temperature in the Arctic is projected to increase steadily under all SRES scenarios, when a tipping point in temperature is reached, an abrupt shift can occur in regional climate types and vegetation. Climate changes are known to have caused large and abrupt shifts in regional vegetation during the Holocene (e.g., Claussen et al. 1999; Cole 2010); this study suggests that warming in the future may also trigger significant shifts in Arctic regional ecosystems.

Figures 3, 4, 5, and 6 all suggest that the observed and projected future climate changes are sufficient to cause large shifts in the spatial distribution of climate types. For successive 15-year intervals, Figure 7 shows the percentage of total area in the Arctic assigned to specific climate types, as compared to the 1950-1999. From the 1900 to 1950 s only about 3-5\% of the total Arctic area 


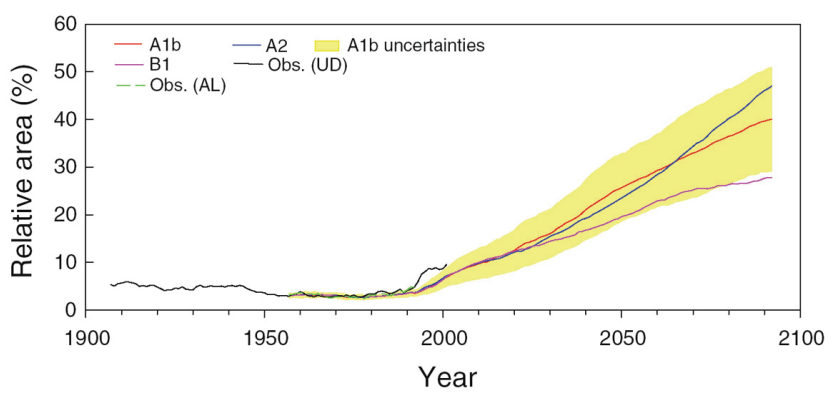

Figure 7. Time series of the percentage of area in the Arctic assigned different climate types compared to the present day condition (1950-1999). A 15-year equal weight smoothing is applied to the observed and projected temperature data before the K-T climate classification is calculated. Then the percentage of area in the Arctic assigned different climate types compared to 1950-1999 during each 15 years interval is calculated.

shows different climate types from 1950 to 1999, suggesting that the climate regimes are fairly stable during this period. The most recent 15 year period (19942008), however, shows distinct differences compared to the 1950-1999 period, with about $9 \%$ of the region having different climate types. This is consistent with the general consensus that the most recent 20 years represents a period with accelerated global warming (IPCC 2007). These recent changes in climate types, however, are dwarfed compared to the projected changes under different SRES scenarios. As shown in Figure 7, the climate types in about 25,39.1, and $45 \%$ of the Arctic are projected to change by the end of this century under B1, $\mathrm{A} 1 \mathrm{~b}$ and A2 scenarios, respectively. In other words, under these emission scenarios, the current dominant vegetation may be replaced by different vegetation by onequarter to nearly one-half of the Arctic land area by the end of this century.

To better understand the differences between the current climate classifications and those projected for the future, the redistributions of climate types during 20402059 and 2080-2089 in the Arctic region are each analyzed. For simplicity, only the projected changes under A1b scenarios are shown in Figure 8. About 26.1\% $(39.1 \%)$ of the Arctic regions are assigned to a different K-T climate type in 2040-2059 (2080-2099) compared to the present-day conditions. As shown in the Figure, major transfers take place from $F t$ to $E c$, and from $E c$ to $E o$ and $D c$ climate types. Additionally, the changes of climate types all follow the same direction, e.g., from colder climate types to warmer climate types. The reduced ice covered regions (Fi) are taken over by $F t$. The large decline in tundra in turn will largely be replaced by Ec. The Ec will be mostly replaced by $D c$ climate. As a result, the area occupied by $D c$ has the largest projected increase, followed by Do and Eo. The
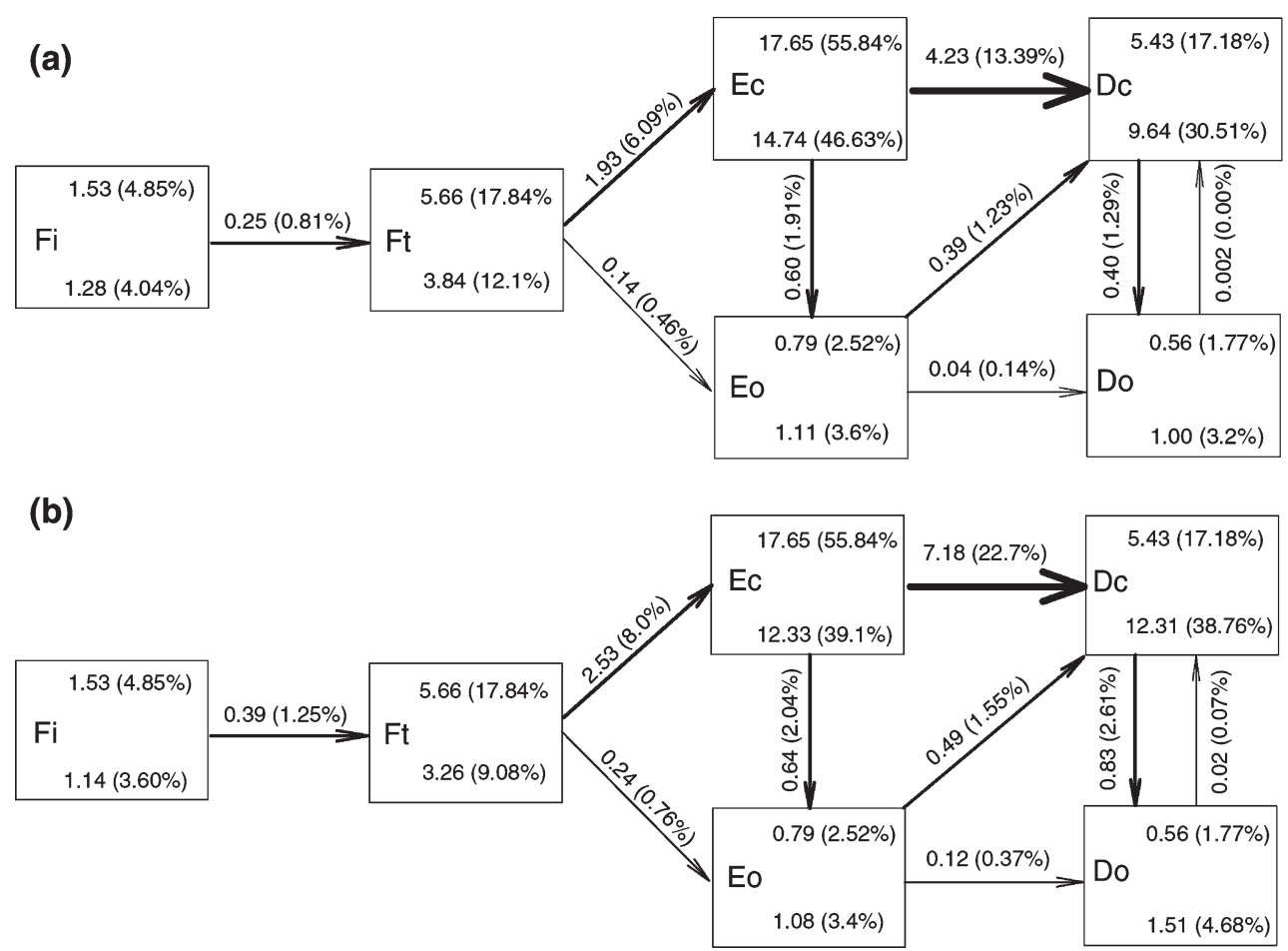

Figure 8. Transfers between different K-T climate types in the Arctic during a 2040-2059 under SRES A1b scenarios. The numbers above/below each climate type indicate the total area (in $10^{6} \mathrm{~km}^{2}$ ) and percentage of total Arctic area (in parentheses) occupied by each type during 1950-1999 and 2040-2059, respectively. The numbers by the arrows indicate redistribution of area and percentage of total Arctic area (in parentheses) between climate types. The results shown are the ensemble of the 16 models. $\mathbf{b}$ is same as a but for 2080-2099 
Polar climate and $E c$ are expected to be reduced substantially with the projected warming in the Arctic region. Though the redistributions of the climate types in Arctic during the 20th century are very small (Figure 7), the much larger redistributions projected for the future suggest that the warming will cause large shifts in climate regimes (Figure 8).

\section{Discussion}

This study used the K-T climate classification to evaluate climate changes in the Arctic, as based on results from a number of global climate models. Because each climate type is associated with a certain vegetation assemblage, the redistribution of climate types suggests concomitant changes in Arctic vegetation. Another approach involves use of models that use appropriate biophysics to 'dynamically' compute the vegetation for a region for a given climate regime. The response of Arctic vegetation to climate change has been simulated by several such dynamic vegetation models, including the Lund-Potsdam-Jena dynamic global vegetation model (LPJ DGVM) (Sitch et al. 2003; Callaghan et al. 2005), the BIOME 4 model (e.g., Kaplan and New 2006; Epstein et al. 2007), the Terrestrial Ecosystem Model (TEM, McGuire et al. 2000; Thompson et al. 2005; Euskirchen et al. 2009), the BIOME-BGC model (Engstrom et al. 2006), the Canada climate-vegetation model (CCVM, Lenihan and Neilson 1995), the Alaska Frame-based Ecosystem Code (ALFRESCO, Rupp et al. 2000), the ArcVeg (Epstein et al. 2000) and the TreeMig model (Lischke et al. 2007). Some of the dynamic vegetation models (e.g., the LPJ DGVM) were incorporated into global climate models to better understand the interactions and feedbacks of vegetation on climate (Levis et al. 1999, 2004). These dynamic models vary in the types and detail of the ecological and biophysical processes incorporated, the controlling and input model variables, and the representation of vegetation types in the Arctic (Epstein et al. 2007). Comprehensive reviews of the vegetation models and their modeling strategies were given by Woodward and Lomas (2004) and Epstein et al. (2007). However, the dynamic models require many input parameters, whose values may not be readily available, especially for future scenarios. These models are also computer-intensive (Epstein et al. 2007), making it impractical to use them to evaluate the impact of climate changes on vegetation when forced by multiple climate models and multiple future scenarios. This is especially important because it has been suggested that, in order to reduce the bias inherent in individual models, an ensemble of multiple climate model outputs are necessary for robust climate change impact assessment (e.g., Gleckler et al. 2008; Reichler and Kim 2008; Pierce et al. 2009).
As mentioned in Sect. 2, a key advantage of the K-T classification is that it is simple, being only defined by temperature and precipitation. Further, the results are easy to interpret and understand. Because of this relative simplicity, it is possible to use the method to evaluate the impact of projected climate changes on vegetation based on numerous, multiple-model outputs and multiple future scenarios. However, like all simple methods, using the K-T climate classification to evaluate vegetation changes has its limitations. For example, the K-T classification is not able to address the effect of $\mathrm{CO}_{2}$ fertilization (Piao et al. 2007) and other non-climate factors, such as local soil type, nutrient limitation, human land use changes, permafrost dynamics, competition among plant species, and wild fire (Hobbie et al. 2002; Goetz et al. 2005; Tchebakova et al. 2009; Soja et al. 2007) on the distribution of local and regional vegetation. Pests and diseases may also expand their geographic ranges as climate warms, increasing stress on vegetation growth (Soja et al. 2007). Therefore, the relationships between climate and vegetation may not be the same in the future as under current conditions. (These limitations also affect dynamical vegetation models.) Moreover, the K-T classification only considers a few climate-vegetation assemblages, which hardly represent the current range of vegetative diversity throughout the Arctic. Importantly, feedbacks of vegetation changes back onto the surface climate cannot be explicitly accounted for. Previous studies (e.g., Chapin et al. 2005; McGuire et al. 2006; Jeong et al. 2010a) suggest that the feedbacks of vegetation on climate can be important and should be considered in future climate change impact assessment.

The K-T classification, though simple and with limitations, has also yielded results consistent with those from the dynamic vegetation models. The K-T classification only identifies a few climate-vegetation assemblages, while the dynamic vegetation models generally provide much more resolution of vegetation types. Therefore, it is impractical to quantitatively compare our results with those of the dynamic vegetation models. Nevertheless, the modern distributions of K-T climate types in the Arctic resemble the major vegetation types simulated by advanced vegetation models (Epstein et al. 2007; Kaplan and New 2006), as well as by what few observational studies exist (e.g., Sturm et al. 2001; Thorpe et al. 2002, Lloyd et al. 2003; Lloyd 2005). For example, Sturm et al. (2001) showed widespread decrease in tundra coverage and a distinct increase in the coverage and density of spruce trees along the tree lines by using long-term ground photographs. Those observed changes in tree lines are consistent with the northward shift of $E_{c}$ and Dc climate types in our results.

Callaghan et al. (2005) summarized modeled Arctic vegetation changes resulting from global warming. They found that most of the dynamic vegetation mod- 
els projected shrinkage of tundra coverage. Much of the tundra (between 11 and $50 \%$, depending on specific region and model) will be replaced by northward shift of boreal forest when the atmospheric $\mathrm{CO}_{2}$ concentrations are doubled. Our results yield 33.0-44.2\% percent shrinkage in tundra coverage by the end of this century, well within the projected changes in tundra coverage made by the dynamic vegetation models. Additionally, the treeline is projected to move north in all sectors of Arctic (Figure 3), which is also consistent with dynamic model projections (Callaghan et al. 2005; Bonan et al. 1992; Foley et al. 1994; Levis et al. 1999; Jeong et al. 2010a). Recent modeling studies (Kaplan and New 2006; Epstein et al. 2007) using BIOME 4 predict that, with a $2{ }^{\circ} \mathrm{C}$ global warming (which possibly will happen by the middle of this century), the boreal forest will move north, with the northern limit trees reaching up to $400 \mathrm{~km}$ from the present tree line. Figure 3 also indicated that the $D c$ climate type will displaced northward by about $2-3^{\circ}$ in the middle of this century, consistent with the BIOME 4 model.

Our results and the dynamic vegetation models all project large redistributions of vegetation in the Arctic region. The changes in vegetation are broadly consistent with observed vegetation changes in the Arctic region (e.g., Sturm et al. 2001; Thorpe et al. 2002, Lloyd et al. 2003; Lloyd 2005). However, the observed rate of change is smaller than the projections in this study and the vegetation models (Callaghan et al. 2005). There are several constraints to vegetation changes, a dominant one being the dispersal of seeds, followed by the germination and establishment of seedlings (Epstein et al. 2007). The response of vegetation therefore usually lags changes in climate. For example, shrub density in tundra regions has seen a rapid increase on decadal time scales (Arft et al. 1999), but boreal forest expansion has seen a much slower response on century time scales (ACIA 2004; Epstein et al. 2007). Furthermore, increasing drought conditions may help offset any potential benefits of warmer temperatures and reduce the overall vegetation growth (biomass) in the Arctic region (e.g., Barber et al. 2000; Angert et al. 2005; Bunn et al. 2007; Jeong et al. 2010b). This suggests that increasing temperature, with no comparable increase in precipitation, may lead to reduced vegetation growth in the future. Other non-climate factors, e.g., local human activity, land use change, permafrost thawing, as well as pest outbreaks and fire may also locally affect the response of vegetation to temperature warming in the Arctic. Therefore, the redistributions of vegetation suggested by the K-T classifications obtained from this study do not mean that the projected changes of vegetation will really happen during this century. More detailed studies accounting for both climate and non-climate factors are needed.

\section{Conclusion}

This study evaluated the temperature changes in the Arctic region (north of $50^{\circ} \mathrm{N}$ ) using observations and simulations for the period 1900-2099 made by 16 fully coupled climate models. Our examination shows multidecadal variations of temperature during the instrumental period, consistent with the temperature record for the entire Northern Hemisphere. A consistent warming in the Arctic is observed since the late 1970s. The recent warm trends are projected to continue under the three SRES scenarios (B1, A1b, and A2). Compared to present-day conditions, the annual temperatures are projected to increase by $2-8^{\circ} \mathrm{C}$ in the Arctic by the end of this century under the A1b scenario. The warming signals in the annual mean temperature are not homogeneously distributed in the Arctic, with the largest warming $\left(>5^{\circ} \mathrm{C}\right)$ in coastal regions, and lesser warming $\left(3-5^{\circ} \mathrm{C}\right)$ in the southern parts of the Arctic (between 50$\left.60^{\circ} \mathrm{N}\right)$. The weakest warming $\left(2-3^{\circ} \mathrm{C}\right)$ occurs in the highlatitude North Atlantic realm. The spatial distribution of the warming signals in winter is very similar to the annual mean temperature, except the magnitude of the warming is stronger, $2-10^{\circ} \mathrm{C}$. The projected warming in summer is much weaker $\left(1.5-4.2^{\circ} \mathrm{C}\right)$, with strongest warming in the southern Arctic, and weaker warming in the Arctic coastal regions. When averaged over the entire Arctic land region, annual mean temperatures in the Arctic are projected to increase by $3.1,4.6$ and $5.3^{\circ} \mathrm{C}$ under the $\mathrm{B} 1, \mathrm{~A} 1 \mathrm{~b}$, and $\mathrm{A} 2$ scenarios, respectively, by 2080-2099. The winter temperature is projected to increase by $4.2,6.1$, and $7.1^{\circ} \mathrm{C}$, and the summer temperature is projected to increase by $2.2,3.3$, and $3.9^{\circ} \mathrm{C}$ under B1, A1b and A2 scenarios, respectively, by the end of this century.

The projected warming leads to large shifts in climate regimes in the Arctic regions. The areas occupied by polar climate types ( $F t$ and $F i$ ) and subarctic continental climate $(E c)$ type are projected to steadily decline, while the areas covered by temperate $(D c$ and $D o)$ and boreal oceanic climate $(E o)$ types are expected to steady expand. The tundra region is projected to decline by $-1.86 \times 10^{6} \mathrm{~km}^{2},-2.4 \times 10^{6} \mathrm{~km}^{2}$, and $-2.5 \times 10^{6} \mathrm{~km}^{2}$, or $-33.0,-42.6$, and $-44.2 \%$ by the end of this century under the $\mathrm{B} 1, \mathrm{~A} 1 \mathrm{~b}$ and $\mathrm{A} 2$ scenarios, respectively. The $E c$ climate type will retreat at least $5^{\circ}$ north of its present day location, resulting in $-18.9,-30.2$, and $-37.1 \%$ declines in areal coverage under the $\mathrm{B} 1, \mathrm{~A} 1 \mathrm{~b}$ and $\mathrm{A} 2$ scenarios, respectively. Following the retreat of tundra and Ec climate types, the temperate climate advances into the areas currently covered by Ec. The area covered by $D c$ climate is expected to expand by $4.61 \times 10^{6} \mathrm{~km}^{2}$ (or $84.6 \%$ ), $6.88 \times 10^{6} \mathrm{~km}^{2}$ (or $126.4 \%$ ) and $8.16 \times 10^{6} \mathrm{~km}^{2}$ (or $149.6 \%$ ) under B1, A1b and A2 scenarios, respectively. The redistribution of K-T climate types differ regionally. In Europe, the areal coverage's of $D c$ and Eo are 
projected to slowly expand until 2040s, then slowly decline. The Do climate, however, is projected to abruptly expand after the 2040s. In Alaska, the regions occupied by boreal climate types (Eo and $E c$ ) are projected to increase until the 2050s, whereas accelerated expansion of temperate climate types (i.e., Do and $D c$ ) is projected after the 2050s. The redistribution of each climate type is slightly smaller under the stabilization B1 scenario compared to the business as usual A1b and A2 scenarios.

Temporal variations of the K-T climate types in the Arctic were also analyzed. The recent 15 year period (1994-2008) shows distinct differences compared to the 1950-1999 period, with about 9\% of the Arctic having different climate types. These recent changes in climate types are projected to continue and be amplified under all three SRES scenarios. The climate types in about 25, 39.1, and $45 \%$ of the Arctic are projected to change by the end of this century under the three scenarios.

Acknowledgments - We thank the editor, Dr. Edwin K. Schneider, and two anonymous reviewers for Climate Dynamics for their constructive comments, which have led to improvement of this manuscript. This research was funded by the Korea Arctic Multidisciplinary Program under grant PP10090, CATER 2006-4204 and by USDA Cooperative Research Project NEB-40-040.

\section{References}

Adam JC, Lettenmaier DP (2003) Adjustment of global gridded precipitation for systematic bias. J Geophys Res 108:1-14

Angert A, Biraud S, Bonfils C, Henning CC, Buermann W, Pinzon J, Tucker CJ, Fung I (2005) Drier summer cancel out the $\mathrm{CO}_{2}$ uptake enhancement induced by warmer springs. Proc Natl Acad Sci 102:10823-10827

Arctic Climate Impact Assessment (ACIA) (2004) Impacts of a warming arctic: Arctic climate impact assessment. Cambridge University Press, Cambridge

Arctic Climate Impact Assessment (ACIA) (2005) Arctic climate impact assessment: Scientific report. Cambridge Univ. Press, Cambridge

Arft AM et al (1999) Responses of tundra plants to experimental warming: Meta-analysis of the international tundra experiment. Ecol Monogr 69:491-511

Bailey RG (2009) Ecosystem geography: From ecoregions to sites, 2nd edn. Springer, New York, p 251

Baker B, Diaz H, Hargrove W, Hoffman F (2010) Use of the Köppen-Trewartha climate classification to evaluate climatic refugia in statistically derived ecoregions for the People's Republic of China. Climatic Change 98:113-131

Barber VA, Juday GP, Finney BP (2000) Reduced growth of Alaskan white spruce in the twentieth century from temperatureinduced drought stress. Nature 405:668-673

Bhatt US et al (2010) Circumpolar Arctic tundra vegetation change is linked to sea ice decline. Earth Interact 14(8):1-20

Bonan GB, Pollard D, Thompson SL (1992) Effects of boreal forest vegetation on global climate. Nature 359:716-718

Bunn AG, Goetz SJ, Kimball JS, Zhang K (2007) Northern high-latitude ecosystems respond to climate change. Eos Trans AGU 88:333-335. doi: 10.1029/2007EO340001
Callaghan TV et al. (2005) Arctic tundra and polar desert ecosystems. In: Arctic Climate Impact Assessment (ed) Arctic climate impact assessment: Scientific report. Cambridge Univ. Press, Cambridge, pp 243-352

Chapin FS III et al (2005) Role of land-surface changes in Arctic summer warming. Science 310:657-660

Claussen M, Kubatzki C, Brovkin V, Ganopolski A, Hoelzmann P, Pachur H (1999) Simulation of an abrupt change in Sharan vegetation in the mid-Holocene. Geophys Res Lett 26:2037-2040

Cole KL (2010) Vegetation response to early Holocene warming as an analogy for current and future changes. Conserv Biol 24:29-37

de Castro M, Gallardo C, Jylha K, Tuomenvirta H (2007) The use of climate-type classification for assessing climate change effects in Europe from an ensemble of nine regional climate models. Climatic Change 81:329-341

Dima H, Lohmann G (2007) A hemispheric mechanism for the Atlantic Multidecadal Oscillation. J Climate 20:2706-2719

Engstrom R, Hope A, Kwon H, Harazono Y, Mano M, Oechel W (2006) Modeling evapotranspiration in Arctic coastal plain ecosystems using a modified BIOME-BGC model. J Geophys Res 111:G02021. doi:10.1029/2005JG000102

Epstein HE, Walker MD, Chapin FS III, Starfield AM (2000) A transient, nutrient-based model of arctic plant community response to climatic warming. Ecol Appl 10:824-841

Epstein HE, Kaplan JO, Lischke H, Yu Q (2007) Simulating future changes in arctic and sub-arctic vegetation. Comput Sci Eng 9(4):12-23

Euskirchen ES, McGuire AD, Chapin FS III, Yi S, Thompson CC (2009) Changes in vegetation in northern Alaska under scenarios of climate change 2003-2100: Implications for climate feedbacks. Ecol Appl 19:1022-1043

Foley JA, Kutzbach JE, Coe MT, Levis S (1994) Feedbacks between climate and boreal forests during the Holocene epoch. Nature 371:52-54

Fraedrich K, Gerstengarbe F-W, Werner PC (2001) Climate shifts during the last century. Climatic Change 50:405-417

Gerstengarbe F-W, Werner PC (2009) A short update on Koeppen climate shifts in Europe between 1901 and 2003. Climatic Change 92:99-107

Gillett NP, Stone DA, Stott PA, Nozawa T, Karpechko AY, Hegerl GC, Wehner MF, Jones PD (2008) Attribution of polar warming to human influence. Nat Geosci 1:750-754

Gleckler PJ, Taylor KE, Doutriaux C (2008) Performance metrics for climate models. J Geophys Res. doi: 10.1029/2007JD008972

Goetz SJ, Bunn AG, Fiske GJ, Houghton RA (2005) Satellite-observed photosynthetic trends across boreal North America associated with climate and fire disturbance. Proc Natl Acad Sci 102:13521-13525

Hinzman LD et al (2005) Evidence and implications of recent climate change in Northern Alaska and other Arctic regions. Climatic Change 72:251-298

Hobbie SE, Nadelhoffer KJ, Högberg P (2002) A synthesis: The role of nutrients as constraints on carbon balances in boreal Arctic regions. Plant Soil 242:163-170

IPCC (2007) Climate change 2007: the physical science basis. In: Solomon S, Qin D, Manning M, Chen Z, Marquis M, Averyt $\mathrm{KB}$, Tignor M, Miller HL (eds) Contribution of working group I to the fourth assessment report of the intergovernmental panel on climate change. Cambridge University Press, Cambridge, p 996

Jeong S-J, Ho C-H, Park T-W, Kim J, Levis S (2010a) Impact of vegetation feedback on the temperature and its diurnal range over the Northern Hemisphere during summer in a $2 \times \mathrm{CO}_{2}$ climate. Clim Dyn. doi: 10.1007/s00382-010-0827-x

Jeong S-J, Ho C-H, Kim B-M, Feng S, Medvigy D, Kim Y-W, Lee $\mathrm{H}-\mathrm{H}(2010 \mathrm{~b})$ Conspicuous circumpolar greening in the 
end of growing season over the Arctic region. J Geophys Res (submitted)

Jia GJ, Epstein HE, Walker DA (2009) Vegetation greening in the Canadian arctic related to decadal warming. J Environ Monit 11:2231-2238

Kaplan JO, New M (2006) Arctic climate change with a $2^{\circ} \mathrm{C}$ global warming: Timing, climate patterns, and vegetation change. Climatic Change 79:213-241

Köppen W (1936) Das geographisca system der Klimate. In: Köppen W, Geiger G (eds) Handbuch der Klimatologie. 1. C. Gebr, Borntraeger, pp 1-44

Lenihan JM, Neilson RP (1995) Canadian vegetation sensitivity to projected climatic change at three organizational levels. Climatic Change 30:27-56

Levis S, Foley JA, Pollard D (1999) Potential high-latitude vegetation feedbacks on CO2-induced climate change. Geophys Res Lett 26:747-750

Levis S, Bonan GB, Vertenstein M, Oleson KW (2004) The community land model's dynamic global vegetation model (CLM-DGVM): Technical description and user's guide. Technical Note NCAR/ TN-459 + IA, National Center for Atmospheric Research, Boulder, Colorado, p 50

Lischke K, Bolliger J, Seppelt R (2007) Dynamic spatio-temporal landscape models. In: Kienast $\mathrm{F}$ et al. (eds) A Changing world: Challenges for landscape research. Springer, Dordrecht, pp 273-296

Lloyd AH (2005) Ecological histories, ecological futures: what recent changes at treeline reveal about the future. Ecology 86:1687-1695

Lloyd AH, Rupp TS, Fastie CL, Starfield AM (2003) Patterns and dynamics of treeline advance on the Seward Peninsula, Alaska. J Geophys Res 108:8150. doi:10.1029/2001JD000570

Matthes H, Rinke A, Dethloff K (2009) Variability of observed temperature-derived climate indices in the Arctic. Global Planet Change 69:214-224

Maurer EP, Adam JC, Wood AW (2009) Climate model based consensus on the hydrologic impacts of climate change to the Rio Lempa basin of Central America. Hydrol Earth Syst Sci 13:183-194

McGuire AD, Clein JS, Melillo JM, Kicklighter DW, Meier RA, Vorosmarty CJ, Serreze MC (2000) Modelling carbon responses of tundra ecosystems to historical and projected climate: Sensitivity of pan-Arctic carbon storage to temporal and spatial variation in climate. Global Change Biol 6(supplementary):141-159

McGuire AD, Chapin FS III, Walsh JE, Wirth C (2006) Integrated regional changes in arctic climate feedbacks: Implications for the global climate system. Annu Rev Environ Resour 31:61-91

Meehl GA, Covey C, Delworth T, Latif M, McAvaney B, Mitchell JFB, Stouffer RJ, Taylor KE (2007) The WCRP CMIP3 multimodel dataset: A new era in climate change research. Bull Am Meteorol Soc 88:1383-1394

Min S-K, Zhang X, Zwiers F (2008) Human-induced Arctic moistening. Science 320:518-520

Nakićenović N, Swart R (2000) Special report on emission scenarios. A special report of working group III of the intergovernmental panel on climate change. Cambridge University Press, Cambridge

Peterson BJ et al (2002) Increasing river discharge to the Arctic Ocean. Science 298:2171-2173

Piao S, Friedlingstein P, Ciais P, Viovy N, Demarty J (2007) Growing season extension and its impact on terrestrial carbon cycle in the Northern Hemisphere over the past 2 decades. Global Biogeochem Cycles 21:GB3018. doi: 10.1029/2006GB002888

Pierce DW, Barnett TP, Santer BD, Gleckler PJ (2009) Selecting global climate models for regional climate change studies. Proc Natl Acad Sci 106:8441-8446
Post E et al (2009) Ecological dynamics across the Arctic associated with recent climate change. Science 325:1355-1358

Reichler T, Kim J (2008) How well do coupled models simulate today's climate? Bull Am Meteor Soc 89:303-311

Rupp TS, Chapin FS III, Starfield AM (2000) Response of subarctic vegetation to transient climatic change on the Seward Peninsula in North-West Alaska. Global Change Biol 6:541-555

Serreze MC, Holland MM, Stroeve J (2007) Perspectives on the Arctic's shrinking sea-ice cover. Science 315:1533-1536

Sitch S, Smith B, Prentice IC, Arneth A, Bondeau A, Cramer W, Kaplan JO, Levis S, Lucht W, Sykes MT, Thonicke K, Venevsky S (2003) Evaluation of ecosystem dynamics, plant geography and terrestrial carbon cycling in the LPJ dynamic global vegetation model. Glob Change Biol 9:161-185

Soja AJ, Tchebakova NM, French NHF, Flannigan MD, Shugart $\mathrm{HH}$, Stocks BJ, Sukhinin AI, Parfenova EI, Chapin III FS (2007) Climate-induced boreal forest change: Predictions versus current observations, Global Planet. Change 56:274-296

Stone RS, Dutton EG, Harris JM, Longenecker D (2002) Earlier spring snowmelt in northern Alaska as an indicator of climate change. J Geophys Res 107:D10, 4089. doi: 10.1029/2000JD000286

Sturm M, Racine C, Tape K (2001) Increasing shrub abundance in the Arctic. Nature 411:546-547

Tchebakova NM, Parfenova E, Soja AJ (2009) The effect of climate, permafrost and fire on vegetation change in Siberia in a changing climate. Environ Res Lett 4. doi: 10.1088/1748-9326/4/4/045013

Thompson CC, McGuire AD, Clein JS, Chapin FS III, Beringer J (2005) Net carbon exchange across the Arctic tundra-boreal forest transition in Alaska 1981-2000. Mitig Adapt Strat Glob Change 11:805-827

Thorpe N, Eyegetok N, Hakongak N, Elders K (2002) The earth is faster now: Indigenous observations of arctic environmental change. In: Krupnik I, Jolly D (eds) Research Consortium of the United States, Fairbanks, AK, pp 201-239

Trewartha GT, Horn LH (1980) An introduction to climate, 5th edn. McGraw-Hill, New York, p 437

Tucker C, Slayback D, Pinzon J, Los S, Myneni R, Taylor M (2001) Higher northern latitude NDVI, growing season trends from 1982 to 1999. Int J Biometeorol 45:184-190

Wang M, Overland JE (2004) Detecting Arctic climate change using Köppen climate classification. Climatic Change 67:43-62

Willmott CJ, Rowe CM, Philpot WD (1985) Small-scale climate maps: A sensitivity analysis of some common assumptions associated with grid-point interpolation and contouring. Am Cartogr 12:5-16

Wood AW, Leung LR, Sridhar V, Lettenmaier DP (2004) Hydrologic implications of dynamical and statistical approaches to downscaling climate model outputs. Climatic Change 62:189-216

Woodward FI, Lomas MR (2004) Vegetation dynamics-simulating responses to climatic change. Biol Rev 79:643-670

Zhang T, Frauenfeld OW, Serreze MC, Etringer AJ, Oelke C, McCreight JL, Barry RG, Gilichinsky D, Yang D, Ye H, Feng L, Chudinova S (2005) Spatial and temporal variability in active layer thickness over the Russian Arctic drainage basin. J Geophys Res 110. doi: 10.1029/2004JD005642

Zhou LM, Tucker CJ, Kaufmann RK, Slayback D, Shabanov NV, Myneni RB (2001) Variations in northern vegetation activity inferred from satellite data of vegetation index during 1981 to 1999. J Geophys Res 106:20,069-20,083 